UDC 519.24

\title{
APPLICATION OF THE FISH SEARCH METHOD FOR OPTIMIZATION PLANS OF THE FULL FACTOR EXPERIMENT
}

Koshevoy N. D. - Dr. Sc., Professor, Head of the Department of Intelligent Measuring Systems and Quality Engineering, National Aerospace University named after N. Ye. Zhukovsky "Kharkiv aviation institute", Kharkiv, Ukraine.

Kostenko E. M. - Dr. Sc., Professor, Vice-rector of the Poltava State Agrarian Academy, Poltava, Ukraine.

Muratov V. V. - Postgraduate student of the Department of Intellectual Measuring Systems and Quality Engineering, National Aerospace University named after N. Ye. Zhukovsky "Kharkiv aviation institute", Kharkiv, Ukraine.

\begin{abstract}
Context. An application of the method of searching for schools of fish to construct optimal experiment plans for cost (time) in the study of technological processes and systems that allow the implementation of an active experiment on them is proposed.

Object of study. Optimization methods for cost (time) costs of experimental designs, based on the application of a school of fish search algorithm.

Objective. To obtain optimization results by optimizing the search for schools of fish for the cost (time) costs of plans for a full factorial experiment.

Method. A method is proposed for constructing a cost-effective (time) implementation of an experiment planning matrix using algorithms for searching for schools of fish. At the beginning, the number of factors and the cost of transitions for each factor level are entered. Then, taking into account the entered data, the initial experiment planning matrix is formed. The school of fish search method is based on the rearrangement of the columns of the experiment planning matrix, based on the sum of the costs (times) of transitions between levels for each of the factors. Fish schools are formed according to the following principle: fewer schools of fish where the sum of the costs (times) of transitions between levels of factors is greater. Then, rearrangements of schools of fish located nearby in the experiment planning matrix are performed. Then the gain is calculated in comparison with the initial cost (time) of the experiment.

Results. Software has been developed that implements the proposed method, which was used to conduct computational experiments to study the properties of these methods in the study of technological processes and systems that allow the implementation of an active experiment on them. The experimental designs that are optimal in terms of cost (time) are obtained, and the winnings in the optimization results are compared with the initial cost of the experiment. A comparative analysis of optimization methods for the cost (time) costs of plans for a full factorial experiment is carried out.

Conclusions. The conducted experiments confirmed the operability of the proposed method and the software that implements it, and also allows us to recommend it for practical use in constructing optimal experiment planning matrices.
\end{abstract}

KEYWORDS: optimal plan, search by school of fish, optimization, experiment planning, cost, win.

\section{NOMENCLATURE}

$k$ - the number of object factors introduced into the study;

$t$ - program run time, $s$

$B$ - winnings;

$N-$ the number of experiments in the planning matrix of the experiment and the matrix of costs of transitions between the levels of factors;

$S_{\text {total }}$ - total cost of the experiment, conv. units;

$S_{i j}$ - the cost of the transition from the $i$-th experience to the $j$-th, conv. units;

$X_{i}$ - the value of the $i$-th factor of the studied process;

$C_{\text {conv }}-$ conversion cost matrix;

$X$-initial plan of the experiment;

$l$-number of iterations of the algorithm;

$l_{i t}$-specified number of iterations of the algorithm;

$a_{i j}$ - the value of the $\mathrm{i}$-th factor in the $\mathrm{j}$-th experiment;

$C_{i j}$ - installation cost of the $\mathrm{i}$-th factor in the $\mathrm{j}$-th experience;

$C_{0}$ - total cost of the experiment.

\section{INTRODUCTION}

The most important part of scientific studies are experiments. This is one of the main ways to get new scien(C) Koshevoy N. D., Muratov V. V., 2020 DOI 10.15588/1607-3274-2020-2-5 tific knowledge. The basis of this method is an experiment, representing a scientifically delivered experience or observation of the phenomenon under precisely taken into account conditions, allowing to monitor its progress, to control it, to recreate it every time when these conditions are repeated. From ordinary, passive observation, the experiment is distinguished by the active influence of the researcher on the phenomenon being studied.

Planning an experiment is a section of mathematical statistics that studies methods for organizing a set of experiments with different conditions to obtain the most reliable information about the properties of the object under investigation in the presence of uncontrolled random perturbations. The use of experimental planning makes the experimenter's behavior purposeful and organized, significantly contributing to the increase of his labor productivity and the reliability of the results obtained. An important advantage of the method is its universality, suitability in the vast majority of areas of research.

The object of study is the technological processes and systems that allow the implementation of an active experiment on them.

The subject of study is the optimization method for cost (time) costs of experiment plans, based on the application of a school of fish search algorithm. 
The purpose of the work is the development of a method and software for optimization of plans for a full factorial experiment using the search algorithm for fish schools.

\section{PROBLEM STATEMENT}

Experimental research methods are widely used to optimize production processes. One of the main objectives of the experiment is to obtain the maximum amount of information about the influence of the factors studied on the production process. Further, a mathematical model of the object under investigation is constructed. At the same time, it is necessary to obtain models with minimal cost and time costs. This is especially important in the study of long and costly processes. Significant disadvantages in their applications are: low speed, not the exact solution is always found, but you can find the solution is only close to optimal. The task of optimizing plans at a cost (time) of the experiment is NP-complete, i.e. for its solution takes time and a large number of computations, rapidly growing with increasing dimension of the problem. Therefore, a complete search of all possible solutions is difficult. In this connection it is necessary to find solutions using approximate algorithms.

The task of optimizing the design of experiments on cost costs is NP-complete, i.e. for its solution, it takes time and a large number of calculations, rapidly growing with increasing dimension of the problem. Therefore, a complete enumeration of all possible solutions is difficult. In this regard, it is necessary to find solutions using approximate algorithms, for example, such as an algorithm of optimization by a swarm of particles.

1. Total cost of the experiment:

$$
C_{0}=\sum_{i=1}^{k} C_{i}+\sum_{j=1}^{N} \sum_{i=1}^{k} C_{i j} \rightarrow \min .
$$

2. Total experiment time:

$$
t_{0}=\sum_{i=1}^{k} t_{i}+\sum_{j=1}^{N} \sum_{i=1}^{k} t_{i j} \rightarrow \min .
$$

\section{REVIEW OF THE LITERATURE}

There are examples of constructing multifactor experimental plans that are based on the use of the following optimization methods: analysis of permutations [1]; method of successive approximation [1]; method of branches and boundaries [1]; random search (permutation of the rows of the planning matrix) [1]; the simplex method [2]; ant algorithm [3]; genetic algorithms [4]; annealing method [5]; greedy algorithm [6]. The effectiveness of the use of methods is also shown in the study of various objects - technological processes, instruments and systems [1, 7-10].

All these methods have both advantages and disadvantages. For example, with a large number of factors, a lot of time is required for a complete search of all the rows of the planning matrix, and other algorithms allow obtaining an optimal experiment plan for a limited number of fac-

(C) Koshevoy N. D., Muratov V. V., 2020 DOI 10.15588/1607-3274-2020-2-5 tors $k$. With a large number of factors, the optimization results are approximated to the optimal experiment plan. In view of this, it is advisable to use the search algorithm for fish by a school to compare the results. Optimization of experiment cost plans full (time) costs by exhaustive search at the current level of computing techniques can only be solved for the number of factors $\mathrm{k} \leq 3$. Therefore, the problem of reduction many plans for a multivariate experiment with minimum number of transitions of factor levels to search for the optimal cost (time) the cost of its implementation.

\section{MATERIALS AND METHODS}

A method and software for optimizing the plans for a full factorial experiment on cost (time) costs using the search algorithm for a school of fish has been developed.

The essence of the application of the search algorithm for schools of fish is as follows:

Step 1. At the beginning of the algorithm is entered the number of factors $\mathrm{k}$.

Step 2. Enter the values of the transitions between the levels for each of the factors.

Step 3. Depending on the selected number of factors, the experiment planning matrix is constructed.

Step 4. Calculation of the initial cost $C_{\text {init }}$ of the experiment.

Step 5. Generate the matrix of the sum of the values of the transitions between the levels for each of the factors.

Step 6. Sort the indexes and generate an array of indexes for the sum of the values of the transitions between the levels for each of the factors.

Step 7. Permutation in the columns in accordance with the array of indices for the sum of the values of the transitions between the levels for each of the factors.

Step 8. Separation of the experiment planning matrix into blocks in accordance with the array of indices for the sums of the values of the transitions between the levels for each of the factors whose dimension is calculated by the formula

$$
N_{\text {blocks }}=2^{(N+1)},
$$

where $N-$ index $(0 \ldots 3)$.

Step 9. Calculation of the local minimum cost of the experiment when the blocks are rearranged.

Step 10. For each column, the permutations of the local blocks of the experiment planning matrix are generated with the calculation of the minimum local sum of the values for each of the columns.

Step 11. Construction of the optimal experiment planning matrix.

Step 12. Calculation of the total cost of the experiment.

Step 13. Calculation of the value of winnings $B$ as the ratio of the initial cost of carrying out the $C_{\text {init }}$ experiment to the cost of the experiment $C_{\min }$.

Step 14. Calculation of the time $t$ spent on optimizing the plan of the full factorial experiment using the search algorithm for fish schools. 


\section{EXPERIMENTS}

Verification of the efficiency of the developed method and software for optimizing the plans for a full factorial experiment was carried out on a number of practical problems. The system for determining fuel consumption in internal combustion engines was studied. At the same time, fuel consumption $q$ in milliliters was considered as an optimization criterion. Factors that affect this indicator were selected: $X_{1}$ - number of revolutions $\mathrm{n}$ of the engine per minute, rpm; $X_{2}$ - engine temperature $T,{ }^{\circ} C[1]$.

The cost of changing the values of the levels of factors are given in table 1 [1].

The initial plan of the full factorial experiment $(k=2)$ and the optimal experiment cost plan, developed using the method of searching for fish by the school, are given in table 2 .

Table $1-$ Costs of changing values of factor levels

\begin{tabular}{|c|c|c|}
\hline \multirow{2}{*}{$\begin{array}{c}\text { Cost of changing levels of factors, } \\
\text { conv. units }\end{array}$} & \multicolumn{2}{|c|}{$\begin{array}{c}\text { Notation } \\
\text { factors }\end{array}$} \\
\cline { 2 - 3 } & $X_{I}$ & $X_{2}$ \\
\hline from «-1» to «+1» & 0,32 & 0,16 \\
\hline from «+1» to «-1» & 0,22 & 0,48 \\
\hline
\end{tabular}

Table 2 - The initial plan of the full factorial experiment and the optimal design of the experiment, developed using the method of searching for fish

\begin{tabular}{|c|c|c|c|c|c|}
\hline \multicolumn{3}{|c|}{ Initial plan } & \multicolumn{3}{|c|}{ Optimal plan } \\
\hline \multirow{2}{*}{$\begin{array}{l}\text { Number of } \\
\text { experience }\end{array}$} & \multicolumn{2}{|c|}{$\begin{array}{c}\text { Notation } \\
\text { factors }\end{array}$} & \multirow{2}{*}{$\begin{array}{l}\text { Number of } \\
\text { experience }\end{array}$} & \multicolumn{2}{|c|}{$\begin{array}{c}\text { Notation } \\
\text { factors }\end{array}$} \\
\cline { 2 - 3 } & $X_{1}$ & $X_{2}$ & & $X_{1}$ & $X_{2}$ \\
\hline 1 & -1 & -1 & 1 & -1 & -1 \\
\hline 2 & +1 & -1 & 2 & +1 & -1 \\
\hline 3 & -1 & +1 & 4 & +1 & +1 \\
\hline 4 & +1 & +1 & 3 & -1 & +1 \\
\hline
\end{tabular}

The cost of the optimal experiment plan obtained by the method of searching for fish by the school is 0.7 conv. units, and the cost of the plan, obtained by the method of full search, is also 0.7 conv. units [1].

The search for the optimal experimental plan $(k=2)$, obtained by the method of searching for fish by the school, was realized in 0.013 seconds.

The win in comparison with the initial planning matrix is 1.46 times, in the work [1] the gain is also 1.46 times.

A study was carried out of the technological process of welding plates of small thickness, in which an experiment was carried out to determine the optimal mode of spot welding of plates of small thickness. The factors considered were: $X_{1}$ - capacitor capacitance, $\mu F ; X_{2}$ - coefficient of transformation, $X_{3}$ - force at the electrodes, $N$ [7].

The cost of changing the values of the levels of the factor are given in table 3 [7].

The initial plan of the full factorial experiment $(k=3)$ and the optimal experiment cost plan, developed using the method of searching for fish by the school, are given in table 4 .
Table 3 - Costs of changing values of factor levels

\begin{tabular}{|c|c|c|c|}
\hline Cost of changing & \multicolumn{3}{|c|}{ Notation factors } \\
\cline { 2 - 4 } levels of factors, conv. units & $X_{1}$ & $X_{2}$ & $X_{3}$ \\
\hline from «-1» to «+1» & 2.5 & 2.0 & 1.5 \\
\hline from «+1» to «-1» & 3.0 & 2.5 & 2.0 \\
\hline
\end{tabular}

Table 4 - The initial plan of the full factorial experiment and the optimal design of the experiment, developed using the method of searching for fish

\begin{tabular}{|c|c|c|c|c|c|c|c|}
\hline \multicolumn{3}{|c|}{ Initial plan } & \multicolumn{4}{|c|}{ Optimal plan } \\
\hline \multirow{2}{*}{$\begin{array}{c}\text { Number of } \\
\text { experi- } \\
\text { ence }\end{array}$} & \multicolumn{3}{|c|}{$\begin{array}{c}\text { Notation } \\
\text { factors }\end{array}$} & \multirow{2}{*}{$\begin{array}{c}\text { Number of } \\
\text { experience }\end{array}$} & \multicolumn{3}{|c|}{$\begin{array}{c}\text { Notation } \\
\text { factors }\end{array}$} \\
\cline { 2 - 5 } \cline { 6 - 8 } & $X_{1}$ & $X_{2}$ & $X_{3}$ & & $X_{1}$ & $X_{2}$ & $X_{3}$ \\
\hline 1 & -1 & -1 & -1 & 1 & -1 & -1 & -1 \\
\hline 2 & +1 & -1 & -1 & 5 & -1 & -1 & +1 \\
\hline 3 & -1 & +1 & -1 & 7 & -1 & +1 & +1 \\
\hline 4 & +1 & +1 & -1 & 3 & -1 & +1 & -1 \\
\hline 5 & -1 & -1 & +1 & 4 & +1 & +1 & -1 \\
\hline 6 & +1 & -1 & +1 & 8 & +1 & +1 & +1 \\
\hline 7 & -1 & +1 & +1 & 6 & +1 & -1 & +1 \\
\hline 8 & +1 & +1 & +1 & 2 & +1 & -1 & -1 \\
\hline
\end{tabular}

The cost of the optimal experiment plan obtained by the method of searching for fish by the school is 14 conv. units, and the cost of the plan, obtained by the method of full enumeration, is also 14 conv. units [7].

The search for the optimal experimental design $(k=3)$ by the method of searching for fish was realized in 0.05 seconds.

The win in comparison with the initial planning matrix is 1.93 times, and in the work [7] the gain is also 1.93 times.

A study of the technological process for the production of parts by hot stamping was carried out. On the basis of a priory information, the thickness of the part was chosen as the criterion for optimizing the process $h_{d e t}$, and the following are the dominant factors: $X_{1}-$ billet heating temperature, ${ }^{\circ} \mathrm{C} ; \mathrm{X}_{2}$ - billet heating time, $\min ; X_{3}$ - temperature of die heating, ${ }^{\circ} \mathrm{C}[1]$.

The time for changing the values of the factor levels is shown in table 5 [1].

The initial plan of the full factorial experiment $(k=3)$ and the experimentally optimal plan for the experiment, developed using the method of searching for fish by the school, are given in table 6 .

The time of realization of the experiment, obtained by the method of searching for the fish by the school, is 74.5 minutes, and the time according to the plan obtained by the full-scan method is 72 minutes [1].

Table 5 - Time of changing values of factor levels

\begin{tabular}{|c|c|c|c|}
\hline Time of changing & \multicolumn{3}{|c|}{ Notation factors } \\
\cline { 2 - 4 } levels of factors, min & $X_{1}$ & $X_{2}$ & $X_{3}$ \\
\hline from «-1» to «+1» & 30 & 22 & 3.75 \\
\hline from «+1» to «-1» & 25 & 5 & 7.5 \\
\hline
\end{tabular}


e-ISSN 1607-3274 Радіоелектроніка, інформатика, управління. 2020. № 2 p-ISSN 2313-688X Radio Electronics, Computer Science, Control. 2020. №

Table 6 - The initial plan of the full factorial experiment and the optimal experimental design, developed using the method of searching for fish

\begin{tabular}{|c|c|c|c|c|c|c|c|}
\hline \multicolumn{4}{|c|}{ Initial plan } & \multicolumn{4}{|c|}{ Optimal plan } \\
\hline \multirow{2}{*}{$\begin{array}{c}\text { Number } \\
\text { of ex- } \\
\text { peri- } \\
\text { ence }\end{array}$} & \multicolumn{3}{|c|}{$\begin{array}{l}\text { Notation } \\
\text { factors }\end{array}$} & \multirow{2}{*}{$\begin{array}{c}\text { Number } \\
\text { of ex- } \\
\text { peri- } \\
\text { ence }\end{array}$} & \multicolumn{3}{|c|}{$\begin{array}{l}\text { Notation } \\
\text { factors }\end{array}$} \\
\hline & $X_{1}$ & $X_{2}$ & $X_{3}$ & & $X_{1}$ & $X_{2}$ & $X_{3}$ \\
\hline 1 & -1 & -1 & -1 & 2 & +1 & -1 & -1 \\
\hline 2 & +1 & -1 & -1 & 6 & +1 & -1 & +1 \\
\hline 3 & -1 & +1 & -1 & 8 & +1 & +1 & +1 \\
\hline 4 & +1 & +1 & -1 & 4 & +1 & +1 & -1 \\
\hline 5 & -1 & -1 & +1 & 3 & -1 & +1 & -1 \\
\hline 6 & +1 & -1 & +1 & 7 & -1 & +1 & +1 \\
\hline 7 & -1 & +1 & +1 & 5 & -1 & -1 & +1 \\
\hline 8 & +1 & +1 & +1 & 1 & -1 & -1 & -1 \\
\hline
\end{tabular}

The search for the optimal experimental design $(k=3)$ by the method of searching for fish was realized in 0.051 seconds.

The gain in comparison with the initial planning matrix is 3.33 times, in the work [1] it is 3.37 times.

A study of a section of a machine tool shop with numerical program control was carried out. As a criterion for optimization, the total operating time of numerical program management machines was chosen. The dominant factors that affect this indicator were selected: $X_{1}-$ time of the prevention $t_{n}, h ; X_{2}$ - number $y_{c}$ of machine tools with numerical program management; $X_{3}$ - machine hours during the day $t_{c}, h ; X_{4}$ - periodicity of prevention $t_{0}, h[1]$.

The time for changing the values of the factor levels is shown in table 7 [1].

The initial plan of the full factorial experiment $(k=4)$ and the experimentally optimal plan for the experiment, developed using the method of searching for fish by the school, are given in table 8 .

Table 7 - Time of changing values of factor levels

\begin{tabular}{|c|c|c|c|c|}
\hline Time of changing & \multicolumn{4}{|c|}{ Notation factors } \\
\cline { 2 - 5 } levels of factors, $h$ & $X_{1}$ & $X_{2}$ & $X_{3}$ & $X_{4}$ \\
\hline from «-1» to «+1» & 7.0 & 6.0 & 16.0 & 100.0 \\
\hline from «+1» to «-1» & 3.0 & 2.0 & 12.0 & 50.0 \\
\hline
\end{tabular}

The time of realization of the optimal experiment obtained by the method of searching for fish by the school is 136 hours. The search for the optimal experimental design $(k=4)$ by the method of searching for fish was realized in 0.14 seconds.

The gain in comparison with the initial planning matrix is 1.85 times, and in the work [1] the gain obtained by the limited search method is 1.17 times.

Thus, as a result of the study of the selected objects, it was shown that the method of searching for fish by the school gives results close to optimal or optimal, both in the method of full search, but in less time in view of the smaller number of necessary transformations.

\section{RESULTS}

A method and a program have been developed optimization of plans for a full factorial experiment using the (C) Koshevoy N. D., Muratov V. V., 2020 DOI $10.15588 / 1607-3274-2020-2-5$ search algorithm for schools of fish. Their operability and efficiency on some examples of research of systems and technological processes are proved.

The search for the optimal or close to the optimal plan obtained by this method is realized in a short time of the account. It is shown that in order to optimize the plans for a full factorial experiment, it is expedient to use the method of searching for fish by research in objects with the number of factors $2 \leq k \leq 4$.

Table 8 - The initial plan of the full factorial experiment and the optimal design of the experiment, developed using the method

\begin{tabular}{|c|c|c|c|c|c|c|c|c|c|}
\hline \multicolumn{5}{|c|}{ Initial plan } & \multicolumn{5}{|c|}{ Optimal plan } \\
\hline \multirow{2}{*}{$\begin{array}{l}\text { Num- } \\
\text { ber of } \\
\text { experi- } \\
\text { ence }\end{array}$} & \multicolumn{4}{|c|}{$\begin{array}{l}\text { Notation } \\
\text { factors }\end{array}$} & \multirow{2}{*}{$\begin{array}{c}\text { Num- } \\
\text { ber of } \\
\text { experi- } \\
\text { ence }\end{array}$} & \multicolumn{4}{|c|}{ Notation factors } \\
\hline & $X_{1}$ & $X_{2}$ & $X_{3}$ & $X_{4}$ & & $X_{1}$ & $X_{2}$ & $X_{3}$ & $X_{4}$ \\
\hline 1 & -1 & -1 & -1 & -1 & 5 & -1 & -1 & +1 & -1 \\
\hline 2 & +1 & -1 & -1 & -1 & 13 & -1 & -1 & +1 & +1 \\
\hline 3 & -1 & +1 & -1 & -1 & 7 & -1 & +1 & +1 & -1 \\
\hline 4 & +1 & +1 & -1 & -1 & 15 & -1 & +1 & +1 & +1 \\
\hline 5 & -1 & -1 & +1 & -1 & 8 & +1 & +1 & +1 & -1 \\
\hline 6 & +1 & -1 & +1 & -1 & 16 & +1 & +1 & +1 & +1 \\
\hline 7 & -1 & +1 & +1 & -1 & 6 & +1 & -1 & +1 & -1 \\
\hline 8 & +1 & +1 & +1 & -1 & 14 & +1 & -1 & +1 & +1 \\
\hline 9 & -1 & -1 & -1 & +1 & 2 & +1 & -1 & -1 & -1 \\
\hline 10 & +1 & -1 & -1 & +1 & 10 & +1 & -1 & -1 & +1 \\
\hline 11 & -1 & +1 & -1 & +1 & 4 & +1 & +1 & -1 & -1 \\
\hline 12 & +1 & +1 & -1 & +1 & 12 & +1 & +1 & -1 & +1 \\
\hline 13 & -1 & -1 & +1 & +1 & 3 & -1 & +1 & -1 & -1 \\
\hline 14 & +1 & -1 & +1 & +1 & 11 & -1 & +1 & -1 & +1 \\
\hline 15 & -1 & +1 & +1 & +1 & 1 & -1 & -1 & -1 & -1 \\
\hline 16 & +1 & +1 & +1 & +1 & 9 & -1 & -1 & -1 & +1 \\
\hline
\end{tabular}

\section{DISCUSSION}

In the study of the system for determining fuel consumption in internal combustion engines for the value of the cost of changing the levels of factors given in table 1, the results of optimizing experimental designs by methods of searching for schools of fish were obtained (table 2). The gain in optimization results when using the school of fish search method is the same as when using the exhaustive search method. The speed of calculations when using the school of fish schools is higher than when using the exhaustive search method.

Based on the study of the system of the technological process of welding plates of small thickness for the value of the cost of changing the levels of factors given in table 3 , the results of optimizing experimental designs by searching for schools of fish were obtained (table 4). The gain in optimization results when using the school of fish search method is the same as when using the exhaustive search method. The speed of computing when using the school of fish search method is higher than when using the exhaustive search method.

Due to the study of the technological process of manufacturing parts by hot stamping for the values of the 
times of changes in the levels of factors given in table 5, the results of optimizing experimental designs by searching for schools of fish were obtained (table 6). The gain in optimization results when using the school of fish search method is the same as when using the exhaustive search method. The speed of calculations when using the method of searching for schools of fish is higher than when using the method of exhaustive search.

In the course of the study of the section of the workshop of machines with numerical program control for the values of the times of the change in the levels of factors given in table 7 , the results of optimizing experimental designs by searching for schools of fish were obtained (table 8). The gain in optimization results when using the school of fish search method is the same as when using the exhaustive search method. The speed of calculations when using the method of searching for schools of fish is higher than when using the method of exhaustive search.

\section{CONCLUSIONS}

In the work, the urgent task of obtaining a sequence of experiments when conducting a full factorial experiment, ensuring its minimum cost or time of the experiment, was solved.

Methods and software have been developed that implement the optimization of multifactor design of experiments using the algorithm of searching for schools of fish. On the examples of technological processes, the efficiency and effectiveness of the proposed method is proved. The study showed that the search for an optimal or near optimal experiment design using the school of fish search method yields good results. Also, this method has high performance indicators. The gains obtained as a result of optimization using this method are significant. Application of the developed methodology and software, based on the use of a school of fish search algorithm, it is effective for a number of factors $k \geq 3$.

The scientific novelty of the work is that for the first time a method is proposed for constructing optimal plans for multifactor experiments, based on the use of a school of fish search algorithm, which will make it possible to build optimal combinatorial plans without exhaustive search of experiment permutation options.

The practical significance of the results of the work lies in the fact that software has been developed that implements the proposed method, as well as experiments have been carried out that have confirmed its efficiency and allow scientists to recommend it in practice when constructing optimal planning matrices for experiments.

Prospects for further research are the application of the developed software on a wider range of practical tasks, in particular for the study of three-level plans for a multifactor experiment, as well as second-order compositional plans.

\section{REFERENCES}

1. Koshevoj N. D., Kostenko E. M. Optimal'noe po stoimostnym I vremennym zatratam planirovanie jeksperimenta. Poltava, izdatel' Shevchenko R. V., 2013, 317 p.
2. Koshovy`j M. D., Koshova I. I., Dergachov V. A., Pavly`k G. V. , Kostenko O. M. Komp'yuterna programa «Programa formuvannya ty`povy`x planiv bagatofaktornogo eksperymentu», svid. pro reyestr. avtor. prava na tvir No74881. Zareyestr v Ministerstvi ekonomichnogo rozvy`tku i torgivli Ukrayiny`21.11.2017.

3. Hoskins D. S. Combinatorics and Statistical Inferecing. Applied Optimal Designs, vol.4, 2007, pp.147-179.

4. Morgan J. P. Association Schemes: Designed Experiments, Algebra and Combinatorics, Journal of the American Statistical Association, 2005, Vol. 100, No. 471, pp. 1092-1093.

5. Bailey R. A., Cameron P. G. Combinatorics of optimal designs, Surveys in Combinatorics, 2009, Vol. 365, pp. 19-73.

6. Koshevoj N. D., Beljaeva A. A. Sravnitel'nyj analiz metodov optimizacii pri issledovanii vesoizmeritel'noj sistemy $\mathrm{i}$ termoreguljatora, Radio Electronics, Computer Science, Control, 2018, No4, pp. 179-187. DOI: 10. 15588/16073274-2018-4-17.

7. Koshevoj N. D., Beljaeva A. A. Primenenie algoritma optimizacii roem chastic dlja minimizacii stoimosti provedenija mnogofaktornogo jeksperimenta, Radio Electronics, Computer Science, Control, 2018, No. 1, pp. 41-49. DOI 10.15588/1607-3274-2018-1-5.

8. Koshevoy N. D. The study of many plans for multifactor experiments with a minimum number of transitions of factor levels, Radio electronics, informatics, control, 2019, No. 2, pp. 53-59.

9. Koshevoy N. D., Kostenko E. M., Pavlik A. V. and others. The methodology of the optimal planning for the cost and time of experiment planning, monograph. Poltava, Poltava State Agrarian Academy, 2017, $232 \mathrm{p}$.

10. Gal'chenko V. Ja., Trembovec'ka R. V., Tuchkov V. V. Zastosuvannja nejrokomp'jutinga na etapi pobudovi metamodelej v procesi optimal'nogo surogatnogo sintezu anten, Visnyk NTUU KPI: Seriia Radiotekhnika Radioaparatobuduvannia, 2018, Issue 74, pp. 60-72. DOI: 10.20535/RADAP.2018.74.60-72.

11. Rodrigues M. I., Iemma A. F. Experimental Design and Process Optimization. N.-Y., CRC Press, 2016, 336 p.

12. Yakovlev S. Convex extensions in combinatorial optimization and their, Springer Optimization and its Applications. Springer, New York, 2017, Vol. 130, pp. 567-584.

13. Firsov S. N., Reznikova O. V. Apparatno-programmnyj kompleks jeksperimental'noj otrabotki processov upravlenija, diagnostirovanija i parirovanija otkazov malyh kosmicheskih apparatov, Pribory i sistemy. Upravlenie, kontrol', diagnostika, 2014, No. 6, pp. 60-69. eLIBRARY ID: 22776434.

14. Bartos B. J. Cleary R. Mc., Dowall D. Mc. Design and analysis of time series experiments. Oxford, Oxford University Press, 2017, 393 p.

15. Berger P. D., Maurer R. E. Experimental Design with Applications in Management, Engineering and the Sciences. Celli New York, Springer, 2018, 640 p.

16. Karpenko A. P. Sovremennye algoritmy poiskovoj optimizacii. Algoritmy, vdohnovlennye prirodoj: uchebnoe posobie. Moscow, izd-vo MGTU im. N. Je Baumana, 2014, $446 \mathrm{p}$.

17. Yakovlev S. V., Pichugina O. S. Properties of combinatorial optimization problems over polyhedral-spherical sets, $C y$ bernetics and Systems Analysis, 2018, No. 1, Vol. 54, pp. 99-109. 
УДК 519.24

\section{ЗАСТОСУВАННЯ МЕТОДУ ПОШУКУ КОСЯКОМ РИБ ДЛЯ ОПТИМІЗАЦІЇ ПЛАНІВ ПОВНОГО ФАКТОРНОГО ЕКСПЕРИМЕНТУ}

Кошовий М. Д. - д-р техн. наук, професор, завідувач кафедри інтелектуальних вимірювальних систем та інженерії якості, Національний аерокосмічний університет ім. М.Є. Жуковського «Харківський авіаційний інститут», Харків, Україна.

Костенко О. М. - д-р техн. наук, професор, Полтавська державна аграрна академія, Полтава, Україна.

Муратов В. В. - аспірант кафедри інтелектуальних вимірювальних систем та інженерії якості, Національний аерокосмічний університет ім. М. Є. Жуковського «Харківський авіаційний інститут», Харків, Україна.

\section{АНОТАЩЯ}

Актуальність. Запропоновано застосування методу пошуку косяком риб для побудови оптимальних планів експериментів за вартісними (часовими) витратами при дослідженні технологічних процесів та систем, що дозволяють здійснювати над ними активний експеримент.

Об'єкт дослідження. Методи оптимізації за вартісними (часовими) витратами, основані на застосуванні алгоритму пошуку косяком риб.

Мета роботи. Отримання результатів оптимізації шляхом оптимізації за допомогою алгоритму пошуку косяком риб за вартісними (часовими) витратами планів повного факторного експерименту.

Метод. Запропоновано метод побудови за вартісними (часовими) витратами реалізації матриці планування експерименту з використанням алгоритму пошуку косяком риб. На початку вводиться кількість факторів і вартість переходів для кожного рівня факторів. Потім з урахуванням введених даних формується початкова матриця планування експерименту. Метод пошуку косяком риб заснований на перестановці стовпців матриці планування експерименту на основі суми вартісних (часових) витрат суми переходів між рівнями для кожного з факторів. Косяки риб формуються за таким принципом: менше косяків риб там, де більша сума переходів між рівнями факторів. Потім виконується перестановка косяків риб, розташованих поблизу в матриці планування експерименту. Також розраховується виграш порівняно з початковою вартістю (часом) експерименту.

Результати. Розроблено програмне забезпечення, що реалізує запропонований метод, який використовувався для проведення обчислювальних експериментів для вивчення властивостей цих методів при вивченні технологічних процесів і систем, що дозволяють здійснювати над ними активний експеримент. Отримані результати оптимальних планів експериментів за вартісними (часовими) витратами порівнюються 3 початковою вартістю експерименту та розраховується виграш у порівнянні з початковим планом експерименту.

Висновки. Проведені експерименти підтвердили працездатність запропонованого методу та програмного забезпечення, яке його реалізує, а також дозволяє рекомендувати його для практичного використання при побудові оптимальних матриць планування експериментів.

КЛЮЧОВІ СЛОВА: оптимальний план, пошук косяком риб, оптимізація, планування експерименту, вартість, виграш.

УДК 519.24

\section{ПРИМЕНЕНИЕ МЕТОДА ПОИСКА КОСЯКОМ РЫБ ДЛЯ ОПТИМИЗАЦИИ ПЛАНОВ ПОЛНОГО ФАКТОРНОГО ЭКСПЕРИМЕНТА}

Кошевой Н. Д. - д-р техн. наук, профессор, заведующий кафедрой интеллектуальных измерительных систем и инженерии качества, Национальный аэрокосмический университет им. Н. Е. Жуковского «Харьковский авиационный институт», Харьков, Украина.

Костенко Е. М. - д-р техн. наук, доцент, проректор Полтавской государственной аграрной академии, Полтава, Украина.

Муратов В. В. - аспирант кафедры интеллектуальных измерительных систем и инженерии качества, Национальный аэрокосмический университет им. Н.Е. Жуковского «Харьковский авиационный институт», Харьков, Украина.

\section{АННОТАЦИЯ}

Актуальность. Предложено применение метода поиска косяком рыб для построения оптимальных планов экспериментов по стоимостным (временными) затратами при исследовании технологических процессов и систем, позволяющих осуществлять над ними активный эксперимент.

Объект исследования. Методы оптимизации по стоимостным (временным) затратам, основанные на применении алгоритма поиска косяком рыб.

Цель работы. Получение результатов оптимизации путем оптимизации с помощью алгоритма поиска косяком рыб по стоимостным (временными) затратами планов полного факторного эксперимента.

Метод. Предложен метод построения по стоимостным (временными) затратами реализации матрицы планирования эксперимента с использованием алгоритма поиска косяком рыб. В начале вводится количество факторов и стоимость переходов для каждого уровня факторов. Затем с учетом введенных данных формируется начальная матрица планирования эксперимента. Метод поиска косяком рыб основан на перестановке столбцов матрицы планирования эксперимента на основе суммы стоимостных (временных) расходов суммы переходов между уровнями для каждого из факторов. Косяки рыб формируются по такому принципу: меньше косяков рыб там, где большая сумма переходов между уровнями факторов. Затем выполняется перестановка косяков рыб, расположенных поблизости в матрице планирования эксперимента. Также рассчитывается выигрыш по сравнению с начальной стоимостью (времени) эксперимента. 
Результаты. Разработано программное обеспечение, реализующее предложенный метод, который использовался для проведения вычислительных экспериментов для изучения свойств этих методов при изучении технологических процессов и систем, позволяющих осуществлять над ними активный эксперимент. Полученные результаты оптимальных планов экспериментов по стоимостным (временными) затратами сравниваются с начальной стоимостью эксперимента и рассчитывается выигрыш по сравнению с первоначальным планом эксперимента.

Выводы. Проведенные эксперименты подтвердили работоспособность предложенного метода и программного обеспечения, которое его реализует, а также позволяет рекомендовать его для практического использования при построении оптимальных матриц планирования экспериментов.

КЛЮЧЕВЫЕ СЛОВА: оптимальный план, поиск косяком рыб, оптимизация, планирование эксперимента, стоимость, выигрыш.

\section{ЛІТЕРАТУРА / ЛИТЕРАТУРА}

1. Кошевой Н. Д. Оптимальное по стоимостным и временным затратам планирование эксперимента / Н. Д. Кошевой, Е. М. Костенко. - Полтава : Шевченко Р. В., 2013. - 317 с.

2. Комп’ютерна програма «Програма формування типових планів багатофакторного експерименту» [М. Д. Кошовий, І. І. Кошова, В. А. Дергачов и др.]: свід. про реєстр. автор. права на твір No74881. - Зареєстр. в Міністерстві економічного розвитку і торгівлі України 21.11.2017 p

3. Hoskins D. S. Combinatorics and Statistical Inferecing / D. S. Hoskins // Applied Optimal Designs. - 2007. - Vol. 4. - P. 147-179.

4. Morgan J. P. Association Schemes: Designed Experiments, Algebra and Combinatorics. // Journal of the American Statistical Association. - 2005. - Vol. 100, No. 471. - P. 10921093.

5. Bailey R. A. Combinatorics of optimal designs / R. A. Bailey, P. G. Cameron // Surveys in Combinatorics. 2009. -Vol. 365. - P. 19-73.

6. Кошевой Н. Д. Сравнительный анализ методов оптимизации при исследовании весоизмерительной системы и терморегулятора / Н. Д. Кошевой, А. А. Беляева // Paдиоэлектроника, информатика, управление. - 2018. No. 4. - C. 179-187. DOI: 10. 15588/1607-3274-2018-4-17.

7. Кошевой Н. Д. Применение алгоритма оптимизации роем частиц для минимизации стоимости проведения многофакторного эксперимента / Н. Д. Кошевой, А. А. Беляева // Радиоэлектроника, информатика, управление. - 2018. - No. 1. - C. 41-49. DOI: 10.15588/16073274-2018-1-5.

8. Кошевой Н.Д. Исследование множества планов многофакторных экспериментов с минимальным числом переходов уровней факторов // Радиоэлектроника, информатика, управление, 2019. - № 2. - Р. 53-59.

9. Кошевой Н. Д. Методология оптимального планирования эксперимента по стоимостным (временным) затра- там : монография / Н. Д. Кошевой, Е. М. Костенко, А. В. Павлик и др. - Полтава : Полтавская государственная аграрная академия, 2017. - 232 с.

10. Гальченко В. Я. Застосування нейрокомп'ютинга на етапі побудови метамоделей в процесі оптимального сурогатного синтезу антен / В. Я. Гальченко, P. В. Трембовецька, В. В. Тучков // Visnyk NTUU KPI: Seriia Radiotekhnika Radioaparatobuduvannia. - 2018. - Issue 74. - P. 60-72. DOI:10.20535/RADAP.2018.74.60-72.

11. Rodrigues M. I. Experimental Design and Process Optimization / M. I. Rodrigues, A. F. Iemma. - N.-Y. : CRC Press, 2016. $-336 \mathrm{p}$.

12. Yakovlev S. Convex extensions in combinatorial optimization and their applications / S. Yakovlev // Springer Optimization and its Applications. - Springer, New York, 2017. Vol. 130. - P. 567-584.

13. Фирсов С. Н. Аппаратно-программный комплекс экспериментальной отработки процессов управления, диагностирования и парирования отказов малых космических аппаратов / С. Н. Фирсов, О. В. Резникова // Приборы и системы. Управление, контроль, диагностика. 2014. - No. 6. - C. 60-69. eLIBRARY ID: 22776434.

14. Bartos B. J. Cleary R. Mc., Dowall D. Mc. Design and analysis of time series experiments. - Oxford, Oxford University Press, 2017. - 393 p.

15. Berger P. D., Maurer R. E. Experimental Design with Applications in Management, Engineering and the Sciences / P. D. Berger, R. E. Maurer. - Celli New York : Springer, 2018. - 640 p.

16. Karpenko A. P. Sovremennye algoritmy poiskovoj opti mizacii. Algoritmy, vdohnovlennye prirodoj : uchebnoe posobie / A. P. Karpenko. - Moscow, izd-vo MGTU im. N. Je. Baumana, 2014. - 446 p.

17. Yakovlev S. V. Properties of combinatorial optimization problems over polyhedral-spherical sets / S. V. Yakovlev, O. S. Pichugina // Cybernetics and Systems Analysis. 2018. - No. 1, Vol. 54. - P. 99-109. 